\title{
Credit Risk and Banks Performance: Evidence from WAEMU Countries
}

\author{
Sangare Kani \\ (Department of economics / Zhongnan University of Economics and Law (ZUEL), Wuhan, China)
}

\begin{abstract}
The banking sector is at the forefront of global concerns. Indeed, given the recent events, researchers agree on the importance of strengthening banks against risks. This study highlights the impact of the credit risk on banking performance in the Member States of the West African Economic and Monetary Union (WAEMU). The analysis includes 20 banks over a 9-year period (2007-2015) using individual specific effects models. The results show a negative and significant effect of credit risk on bank performance measured by ROA (return on assets). Therefore, taking extreme measures to reduce credit risk has a considerable impact on the profitability of banks. The economies of the States require investment and financing, but they are caught up in the West African banking paradox. Banks should review their lending policy and inject more flow into the economy while improving their risk prevention measures in harmony with the social and economic realities of these countries.
\end{abstract}

Keywords: Banks performance, credit risk, West African Economic and Monetary Union (WAEMU)

\section{Introduction}

Financial institutions such as banks perform an essential mission in the economy through the financial services they provide. Today, banks are the largest financial institutions in the world, with subsidiaries and branches in everyone's life. The circuits of intermediation between savings and investment are very important. The soundness of the banking industry is an important condition for stability, growth and efficient allocation of capital in the economy through efficient and effective performance. When they are effective, financial intermediaries can mobilize the share of incomes retained by households to use them for beneficial (more productive) purposes, benefiting not only investors but also their beneficiaries and the economy. The banking system seeks to better limit, quantify, globalize and negotiate all risks associated with an operation, but this should not impair its incentive to invest. In order to promote the performance of financial systems, restructuring policies have been developed in developing countries.

The acceleration of economic growth necessarily involves an increase of productive investment with an implementation of reforms and adequate quality policies. The WAEMU countries all present for their economic's agent difficulties in accession to bank credit. Banks play a key role in financing the private sector, the engine of growth. The area has at its active 131 banks and a common central bank. The economy of the WAEMU should be partly financed by them. The Central Bank of the States of West Africa (BCEAO), International Public corporation whose Seat is located in Dakar (Senegal) is the Issuing house common to the eight States members of the West Africa Economics and Monetary Union (WAEMU): Benin, Burkina Faso, the Ivory Coast, the Guinea-Bissau, Mali, Niger, Senegal and Togo.

In the WAEMU zone, banks remain the main financial intermediaries. The importance of the commitments they undertake and the systemic risk that their failure poses to the whole economy justifies their special status among commercial enterprises. The banking system in sub-Saharan Africa has undergone many changes since independence. Despite these important advances, bankers are exposed to high-risk positions that could compromise their solvency. Their credit function should improve the ability of investors to operate desirable and profitable enterprises (this function of banks is one of the biggest problems of the WAEMU).

Credit risk arises because it is possible that a borrower will not meet its obligations for several reasons. This risk, known as insolvency risk, is essential in the banking sector as it is the main revenue generating activity for banks. Therefore, it reflects the latter's ability to create wealth. This objective, which is not an end in itself, contributes to the development and sustainability of commercial activities. It is understandable that lending risk assessment remains the main concern of these institutions. Thus, any decision of a bank involves the evaluation of a risk, therefore an anticipation of the expected evolution of each situation.

The uncertainty of the activity is the foundation of the banking profession. This is where the role of financing the economy makes sense. Past events provide insight into the importance of the financial system, which leads the regulator to introduce stricter rules. These rules make the banking system more constrained, but sustainability is the goal. Since its creation, the WAEMU monetary policy aimed at promoting the economic

sectors called driving sectors, by the principle of preferential interest rates. It must be said that this policy did not give the expected results (the 80-90 crisis leading to bankruptcy twenty-seven banks). It is very interesting to see how profitability is affected by the risks incurred by commercial banks. 
Many have devoted their research to this subject. The opinions and results of each differ on whether the management of credit risk has an effect on the performance of banks. This subject deserves attention, the current financial situation of WAEMU countries, in particular motivates its study. It is imperative to provide more information on this subject in order to give a broader view of the subject in favour of safer banking intermediation. Developments in the financial sector and financial instruments are continuously highlighting the shortcomings of the international financial system. The control and monitoring of banking risks, particularly in countries where financial vulnerability is systemic, has become a major problem. This study highlights the impact of the underlying factors of credit risk on the performance of banks taking into account the movement of risk from one state to another in the West African Economic and Monetary Union. It should assess the main tools used to identify credit risk and show their degree of impact on the performance of banks.

\section{Literature Review}

The impact of credit risk on bank performance is always a critical issue. This desire for analysis and resolution of the problem took more importance since the crisis of 2007. Indeed, there were many who analyzed the credit risk relating to banking activity.

\subsection{THEORITICAL BACKGROUND}

A bank is a Credit institution carrying out transactions with individuals, companies and public authorities, of collecting funds for redistribution in the form of credit or performs ancillary investment transactions. It is naturally a function of three parameters: the amount of the debt, the probability of default and the proportion of the debt that will not be recovered in the event of default. Since banks are not immune to economic fluctuations, they must assess credit applications carefully to minimize credit risk (Ousmane Bah 2008). The main source of credit risk are volatile interest rates, limited institutional capacity, inadequate credit policies, volatile interest rates, poor management, capital levels and low liquidity, direct loans, bad lending practices, massive licensing of banks, poor underwriting the loan, the lax credit assessment, government interference and inadequate supervision by the central bank, inappropriate laws (Kithinji, 2010).

The banking industry is heavily dependent on information, often faced with a problem of asymmetry of information due to the informational opacity of borrowers. the bank can acquire two types of information: hard, soft and externally, internally. This involves two methods of allocation of loans: the bank act versus relationship banking (GC Brigitte and Christophe JG 2005). Thus, the construction of information discrimination justified by risk levels seems conditioned by the size of the parties. The information collection requirements will be reflected in the cost of bank indebtedness (Bédué Agnes Levy Nathalie1997). The failures in financial intermediation can disrupt the development process (Abhiman and Saibal 2007). The general rule is that a company should focus its attention on two types of risk: the risk of low frequency and high severity and the risk of high frequency, low severity (Olivier Hassid 2008). Credit risk management maximizes the risk-adjusted rate of return based on bank holding of credit risk within the acceptable limits to provide the framework for understanding the impact of credit risk management on profitability banks (Kargi, 2011).

The credit is a recurring operation especially in this environment where liquidity is almost nonexistent thing at the customer (company, individual) (Ousmane Bah 2008). Any credit carries the risk that revenues do not occur and no reimbursement or refund only "individuals" at maturity. This risk (insolvency risk) is essential in the activity of the bank (Diane \& Fatou Diop Mouhamadou B. 2007). The risk is therefore binds to uncertainty (variability of gains or losses), but also has its negative consequences: the risk of winning is rarely mentioned! Variability is measured by earnings volatility, while the negative consequences of a risk are measured by VAR (Value at Risk) (Vivien Brunel 2009). The consequences of a given risk depend on the probability of occurrence of the disaster, also called frequency and the amount of potential loss (severity) (Olivier Hassid 2008). However, the loss of the default of the bank did not need to be big and good risk management seeks to avoid high-risk exposure. To minimize their risk exposure banks adopt risk-control measures such as: credit derivatives, credit securitization, compliance with the Basel Accord, adoption of a sound internal policy loan and credit bureau (Kolapo, T. Funso, AYENI, Kolade OKE and Mr. Ojo 2012). "The Credit Derivatives encourages banks to lend more than they would at lower rates to riskier borrowers" according to Frank Partnoy and David Skeel in 2006.

Banks can set up a formalized process for their risks which are identified, analyzed and measured. The sources of information that may be useful in this process are multiple (Olivier Hassid 2008). Various studies found governance mechanisms valid for firms, in general are not suitable for banks which justify the intervention of regulatory authorities. The specific regulation essentially aims to ensure their solvency, liquidity, depositor protection and, in general, the security of the banking system as a whole (UEMOA Bankers guide 2014). The strict observance of these rules is a guaranteed way for banks in the management of the risks they face in exercising the profession. The only capital requirements may not be sufficient to limit bank risk and additional requirements may be useful to reduce risk in a competitive environment. In fact, the interdependence 
between financial deregulation, risk taking and the market power of banks, is not enough to explain by itself the credit risk.

\subsection{EMPIRICAL REVIEW}

In recent years, researchers at the financial and banking sector were many interested by the factors responsible of the vulnerability of the banking sector.

Allen and Gale (2004) from their observation, found that the aspects of performance, efficiency and the stability of banks are inter-related. So, a careful consideration of all important prudential measures is very important for a sound empirical analysis.

Kargi (2011) evaluated the impact of credit risk on the profitability of Nigerian banks. Results showed that the credit risk management has a significant impact on the profitability of Nigerian banks. In conclusion, bank profitability is inversely influenced by the levels of loans and advances to non-performing loans and deposits, thus exposing them to a large liquidity risk and distress. The risk is the potential that current and future events, expected or unanticipated may have an adverse or harmful impact on the institution's capital, earnings or achievement of its objectives (Mbeba 2007).

Indiael Kaaya and Dickson Pastory (2013) studied the relationship between credit risk and the performance of the bank as measured by the return on assets. They found that credit risk indicators produced a negative correlation indicating that the higher the credit risk, the lower the bank's performance. Hence the adoption of too protective measures leads to an effective decline in bank profits. This study showed the negative effect of overprotective management on the profits of Tanzanian banks.

Kithinji (2010) evaluated the effect of credit risk management on the profitability of commercial banks in Kenya. The results revealed that most of the profits of commercial banks are not influenced by the amount of credit and non-performing loans, so other variables other than credit and non-performing loan impact on profits.

Kolapo, Ayeni and Oke (2012) showed that credit risk management had a positive relationship with bank profitability in Nigeria but the same study carried out for banks in Indonesia shows a negative relationship. Others have examined the impact of possible changes in prudential standards for the classification of loans on the banks' credit portfolio (Das and Ghosh, 2007). While some studies claim that the credit risk management positively affects economic performance of banks, others find the negative effect.

Credit risk has different effects on the financial performance of banks from a country to an other one. It depends on country and bank management systems they depend on. Felix and Claudine (2008) investigated the relationship between bank performance and credit risk management, from their findings the return on assets measuring profitability was inversely related to the ratio of non-performing loan to total loan of financial institutions thereby leading to a decline in profitability. Under backward-looking provisioning practice, where provisions are triggered by default incidents on loans, higher levels of non performing loans are associated with high rates of provisioning (Hasan and Wall, 2004). Loan loss provisions is a controlling mechanism over expected loan losses.

Al-Khouri (2011), has found that credit risk, liquidity risk and capital risk are the major factors that affect bank performance when profitability is measured by return on assets. It could be inferred from the conclusion of several studies that the return on assets is the most reliable indicator in matters of credit risk estimation. The main determinants of the credit risk of commercial banks on banking systems in emerging economies compared with developed countries were examined by Ahmad and Ariff (2007). Their study showed a strong significant regulation for banking systems that offer multiple services and various products; Quality management is crucial in the case of dominant loans banks in emerging economies. An increase in the provision for loan losses was considered as a determinant of potential credit risk. Therefore, she put out the high level of credit risk incurred by banks in emerging economies.

\section{Methodology}

This study aims to analyse the impact of credit risk on the performance of commercial banks in WAEMU. This study main goal to highlight the different factors that react on banking activity through the main financial element that may have impacted on its profitability.

\subsection{DATA AND SAMPLE DESCRIPTION}

The research is based on a sample comprising commercial banks from UEMOA countries, namely Mali, Togo, Ivory-Cost, Senegal, Benin, Niger, Burkina Faso and Guinea Bissau . The sample size is based on the following criteria:

- the availability of consistent data;

- Each bank is one of the largest banks in the WAEMU countries where it is located to cover loans

Render more possible;

- Banks do not participate in a merger during the study period, so that the result or work of another 
The company does not interfere;

The amount of information contained in the panel data is very high. The ability to discriminate between alternative hypotheses becomes considerably greater when working with this type of data. Therefore, samples will be organized over a period of 9 years for 20 banks (2007 to 2015) using the individual effects model. Data were collected from some selected banks, Bank scope and the World Bank database. The choice limited to 20 banks is due to the lack of data on banks in the region covering the period of study.

\subsection{VARIABLES DEFINITION}

This study aims to analyze the impact of the credit risk management on the financial performance of banks measured by ROA. In this study, the ROA is taken as the indicator of the profitability of banks. ROA is the indicator that best express the profitability of the bank (its ability to generate resources, expressing by the same occasion its management quality). In fact, this ratio is not impacted by leverage. In a need to quantify banks' credit risk management and bank performance by establishing the relationship in a econometric objective method, the study examines the relationship between the three indicators chosen to represent or measure the credit risk management as well as three control variables for an overview on the management of the events and the dependent variable chosen to represent profitability and performance.

ROA: Return on Assets

The efficiency ratio, or "return on assets" (ROA) is a fundamental element in the profitability and performance of a bank, this ratio measures earnings of the business before interest and taxes against its net assets total. This ratio provides information on the use made by a company of its assets to generate profits. This ratio is calculated by comparing net profit with total net assets of a company.

IOL: Interest on loans

This variable represents the interest charged by the bank on its credit operations. It also expresses the levels of bank levy. It represents therefore, the level of earnings that the company gains on its credit activity independently of other activities. A mismanagement of this variable leads to an increase in credit risk.

NPL: Non-Performing Loan

The loan is said non-performing when it reaches more than 90 days late. This variable has to have an overview on a number of uncovered loans it's an indicator of the financial strength which demonstrates the quality of bank loans and therefore a crucial factor for the management of credit risk. When it increases, the risk becomes high and reduces the inflow expected by the bank.

LLP: loss loan provision

The allowance for loan losses is a balance sheet account that represents the best estimate of future losses that banks expect on their loans. It is an indicator of how a bank is protected against future losses it could have. An increase in this variable shows the state of caution shown by the bank vis-à-vis its loans granted.

IM: Interest Margin

Macro-prudential monitoring of the banking system is determinant in order to appreciate the financial stability. This variable can provide a relative comparison. It reflects the cost of the intermediation services provided by banks and also their efficiency. The interest margin beyond and its threshold moves in the same direction as the credit risk. The interest rate is a key factor in the portfolio of a bank. This variable represents the dorsal thorn of the banking activity.

GGR: GDP growth rate

The crises are linked to volatile nature of international capital and strong interconnection of financial systems causing the rapid spread of risks. On time of GDP growth declining, the demand for credit falls, which in return negatively affect the profitability of banks GDP as the control variable, therefore, allows control of capital whose main purpose is to address the negative externalities arising from the volatility of capital flows. An overall improvement in the country's financial situation and by the occasion of its population financial resources results in lower default risk. The GDP growth rate is an indicator of the economic conditions of the area in which the profession is exercised (best prospects for returns on loans).

IR: Inflation rate

Inflation being the speed at which the general level of prices of goods and services is on the rise in a country so it therefore reflects the purchasing power of the currency and increases credit rationing, this variable enables an analysis of the environment in which evolves the bank.

\subsection{MODEL SPECIFICATION}

This study analysed the Individual specific effects model. The econometric model used in this study can therefore be written in this way:

$Y_{i t}=\beta_{0}+\beta_{1} X_{i t}+e_{i t}$ 
$Y$ is the dependent variable;

$\beta_{0}$ is the constant;

$\beta_{1}$ is the coefficient of the explanatory variables;

$X_{i t}$ is the explanatory variable;

$e_{i t}$ is the error term.

Some variables in the model will be "log" to reduce the volume of numbers showing a series in order to avoid too much standard deviation. The model chosen for this study is based on a mix of the model used by Kargi (2011) in his study "Credit Risk and Performance of Nigerian Banks" and Vincent Okoth Ongore and Gemechu Berhanu Kusa (2013) in their study of "Determinants of Financial performance of commercial banks in Kenya. "This amounts to writing the model as follows:

$$
R O A_{i t}=\beta_{0}+\beta_{1} \ln I O L_{i t}+\beta_{2} \ln N P L_{i t}+\beta_{3} \ln L L P_{i t}+\beta_{4} I M_{i t}+\beta_{5} G G R_{i t}+\beta_{6} I R_{i t}+e_{i t}
$$

\section{Empiracal Results}

The panel data model (with STATA) helps us to describe individual behavior across time and between individuals. To determine the impact that the independent variables have on the dependent variable, the descriptive statistics is in the foreground followed by the variance inflation factor (VIF) estimate to quantify the severity of multicollinearity. The following steps present the estimation of individual specific effects. With panel time series data, the most frequently estimated models of individual specific effects are fixed effects and random effects models. The hypothesis on the random effects model is that the individual specific effects are not correlated with the independent variables. The assumptions about the fixed effect are the individual specific effect correlated with the independent variables. It should therefore, be noted that if the random effects hypothesis is chosen, the random effects model is unequivocally more efficient than the fixed effects model, this is also true for the fixed effects model. The choice between the two effects depends on the Hausman test result. After obtaining the specific individual effect of the study, the Breusch-Pagan Lagrange multiplier (LM) must be tested to confirm the choice of the Hausman test. The test to detect if there is a heteroskedasticity must also be tested.

\subsection{DESCRITIVE STATISTICS}

The summary of the statistics for all the variables used in the model is presented in Table 1. For each variable, the table reports the mean, standard deviation, minimum and maximum values.

Table 1: Descriptive statistics of variables

\begin{tabular}{l|l|l|l|l}
\hline Variables & Mean & Std.Dev & Min & Max \\
\hline ROA & 1.3700 & 2.2006 & -8.37 & 4.178 \\
Ln NPL & -2.5114 & 0.9968 & -6.1291 & 0.7810 \\
Ln LLP & 6.4678 & 2.2301 & 2.5649 & 9.8416 \\
Ln IOL & 8.1638 & 1.1538 & 4.8202 & 10.8170 \\
IM & 5.7533 & 1.4109 & 1.4990 & 9.8720 \\
GGR & 4.6419 & 2.7139 & -4.3872 & 11.8136 \\
IR & 4.3992 & 2.6694 & -2.2480 & 11.3051 \\
\hline
\end{tabular}

Source: Author's computation

The ROA has an average of 1.3700 with a standard deviation of 2.2006 which gives an overview of the profits generated by the sampled banks. The banks recorded a high profit with a significant variation between the banks. According to the table NPL varies from -6.12 to 0.78 which is high with an average of -2.51 and a std.dev. From 0,9968. These figures show the virtual absence of volatility between banks ability to manage credit risk. The LLP variable shows a high volatility in banks' management of provisions. LnIOL and IM Std.dev are respectively 1.15 and 1.41 which confirm that the banks are in competition in terms of percentage of interest.

\subsection{VARIANCE INFLATION FACTOR (VIF)}

In a multiple regression model, it is generally assumed that the independent variables are independent among them, only Y may depend on other variables. The VIF test shows whether the multiple regression model hypothesis is respected. VIF above 5 shows the existence of multicollinearity. If the VIF of a variable exceeds 5 , that variable is said to be highly collinear. 


\begin{tabular}{|l|cc|}
\multicolumn{3}{c}{ Table 2: VIF test result } \\
\hline Variable & VIF & 1/VIF \\
\hline InIOL & 4.90 & 0.20 \\
InLLP & 4.11 & 0.24 \\
InNPL & 2.14 & 0.46 \\
IM & 1.94 & 0.51 \\
IR & 1.33 & 0.75 \\
GGR & 1.15 & 0.86 \\
\hline Mean VIF & & 2.60 \\
\hline
\end{tabular}

Source: Author's computation

The result of VIF test is acceptable which means there is no multicollinearity in the model .

\subsection{INDIVIDUAL SPECIFIC EFFECTS}

Table 3 presents the results of the fixed effects model and the random effects model as well as the Hausman test result which allows to choose between these two effects.

Table 3: Random effect (RE) and fixed effect (FE) specification test

\begin{tabular}{|l|l|l|l|l|}
\hline & \multicolumn{2}{|c|}{ FE } & \multicolumn{2}{c|}{ RE } \\
\hline \multicolumn{1}{|c|}{ Dependant variable ROA } & Coef. & T-stat & Coef. & T-stat \\
\hline Constant & -4.63 & $-2.70^{*}$ & -5.07 & $-3.96^{*}$ \\
lnNPL & -0.73 & $-3.36^{*}$ & -0.55 & $-3.18^{*}$ \\
nnLLP & -0.38 & $-2.39^{* *}$ & -0.45 & $-3.43^{*}$ \\
LnIOL & 0.44 & $2.18^{* *}$ & 0.64 & $4.37^{*}$ \\
Im & 0.49 & $5.52^{*}$ & 0.44 & $5.75^{*}$ \\
GGR & 0.07 & $1.80^{* * *}$ & 0.68 & 1.60 \\
IR & -0.04 & -0.99 & -0.05 & -1.20 \\
\hline Prob >chi2 & 0.000 & 0.000 & \\
rho & .3679442 & .2563929 & \\
\hline Hausman test & Prob>Chi 2 $=0.3753$ & & \\
& &
\end{tabular}

Note: $*$ means statistically significant at the $1 \%$ level

** means statistically significant at the $5 \%$ level

*** means statistically significant at the $10 \%$ level

Absence of stars means statistically not significant

Source: Author's computation

The $\mathrm{P}$ values in the table lead to reject the null hypotheses in both models and validate the presence of fixed effects and random effects at a level of risk of 5\%. The intraclass correlation "rho value" shows for the fixed effects model that around $36.79 \%$ of the variance is due to differences across panels and for the random effects $25.63 \%$ of the variance is due to differences across panels. The Hausman test null hypotheses assumes that the preferred model is random effects vs. the alternative is the fixed effects. According to the result, the best individual specific effects model is the random effects model

\subsection{ADDITIONAL TESTS}

The Breusch-Pagan lagranger multiplier test (LM) helps to decide between a regression by random effects and a simple regression of the OLS. Its null hypothesis assumes that the variances between entities are zero. For the model applied to this study, the value of Prob >chibar2 $=0.0007$ confirms the effectiveness of the random effects model compared to the OLS.

Heteroskedasticity exists in the model if the variance of the error terms distribution changes for each observation or range of observations. His null hypothesis assumes that the model is homoskedastic. Depending on the value of Prob>chibar2 $=0.1337$, the alternative hypothesis can be rejected. The model is therefore homoscédastic, the values obtained in the various analyses are reliable.

\section{Conclusion}

Based on the Hausman test result, the random effect model is the effective individual-specific effect model. From the results, all variables are significant except GGR and IR. GDP growth has a non-significant positive relationship with the ROA, but inflation has a non-significant negative impact on the ROA. Contrary to several studies that have shown a relationship between the macroeconomic instability of some countries with the degree of risk aversion of their banks, this study shows that in the WAEMU area the profitability of banks is not directly related to the economic situation of the countries. NPLr and LLP have negative relationships with the ROA. Indeed, an increase in non-performing loans and loss loans provisions would have reduced bank yields by 
0.55 and 0.45 respectively. The study shows that the interest rates given and received by banks have a concise margin that positively affects banking performance. It also highlights the presence of the application of very high-interest rates. The evolution of banking activity in an unstable environment is not easy. The study was designed to highlight the impact of risk management on bank performance in the WAEMU countries. Banks in their desire to protect themselves from risk have adopted protectionist measures leading to the freezing of the economy. This is also due to excessive interest rates, which constitute a major obstacle to economic activity. Indeed, this study revealed the presence of a high rate of pay which should be revised downwards in order to promote investment. It focuses on the high degree of risk aversion, leading to higher risk premiums and low credit demand. It is therefore, important to establish effective internal control systems to identify, measure, monitor and control loans in order to improve the credit risk management process.

\section{Acknowledgements}

I especially thank my family, my sisters, my brothers and all my relatives, who accompanied me, helped, supported and encouraged throughout the completion of this article and especially my father and my mother Birama SANGARE and Aminata TRAORÉ for their support and unwavering love that accompanied me all my life, during all my work and all my studies. I thank all those without whom this article would not be what it is, both by the discussions I have been fortunate to have with them, suggestions or moral support. Especially the encouragement and moral assistance from Adama SANGAFE, allowed me to make that work in good conditions, for this, I warmly thank him.

\section{References}

[1]. O. Bah, La Gestion du Risque de Crédit: un enjeu majeur pour les banques, Master diss, Université of Dakar Bourguiba, Senegal, 2008.

[2]. A. M. Kithinji, Credit Risk Management and Profitability of Commercial Banks in Kenya, School of Business, University of Nairobi, Kenya, Nairobi, 2010.

[3]. B. Godbillon-Camus and C. J. Godlewski, Gestion du Risque de Credit dans la Banque : Information Hard, Information Soft et Manipulation, University Robert Schuman, Strasbourg III, 2005.

[4]. A. Bédué, \& N. Lévy, Relation Banque-entreprise et le coût du crédit, Journal of Financial Economics, 1997, No. 39. p. 179-200.

[5]. D. Abhiman and S. Ghosh, Determinants of Credit Risk in Indian State-owned Banks: An Empirical Investigation, Economic Issues, 2007, Vol. 12, No. 2. p. 48-66.

[6]. O. Hassid, Management of risk (Paris, DUNOD Edition 2, 2008).

[7]. H.S. Kargi, Credit Risk and the Performance of Nigerian Banks, Department of accounting, Faculty of Administration, Ahmadu Bello University, Zaria - Nigeria, 2011.

[8]. I. Kaaya, \& D. Pastory, Credit Risk and Commercial Banks Performance in Tanzania: a Panel Data Analysis, Research Journal of Finance and Accounting, 2013, ISSN 2222-1697.

[9]. F. Diane, \& B.D. Mouhamadou, Credit Risk Management and Financing of WAEMU economies (Senegal, Ministry of Economy and Finance, 2007).

[10]. V. Brunel, Risk Management and Credit Risk (Paris, ECONOMICA, 2009).

[11]. M.O. Oke, R.K. Ayeni and T.F. Kolapo, Credit risk and commercial Bank`s performance in Nigeria: A Panel model approach, Ekiti State University, Ado-Ekiti, Nigeria, 2012.

[12]. R.P.S. Poudel, The impact of credit risk management on financial performance of commercial banks in Nepal, Doctoral diss., Business School University, New England Australia, 2012.

[13]. F. Allen and D. Gale, Competition and financial stability, Journal of Money, Credit and Banking ,2004, No.36, 453-80.

[14]. A. Das and S. Ghosh, Determinants of Credit Risk in Indian State-owned Banks: An Empirical Investigation, MPRA, Paper17301, 2007.

[15]. A.T. Felix and T.N. Claudine, Bank Performance and Credit Risk Management, Masters diss., University of Skovde, Sweden, 2008.

[16]. I. Hasan and L.D. Wall, Determinants of the Loan Loss Allowance: Some Cross-country Comparisons, Financial Review, 2004, Vol. 39, no.1, p. 129-152.

[17]. R. Al-Khouri, Assessing the Risk and Performance of the GCC Banking Sector, International Journal of Finance and Economics, 2011, ISSN 1450-2887.

[18]. N.H. Ahmad and M. Ariff, Multi-country Study of Bank Credit Risk Determinants, International Journal of Banking and Finance, 5(1), 135-152, 2007.

[19]. V.O. Ongore and G.B. Kusa, Determinants of Financial Performance of Commercial Banks in Kenya, International Journal of Economics and Financial Issues Vol. 3, No. 1, ISSN: 2146-4138, 2013.

[20]. R.B. Mbeba, MFI Internal Audit and Controls Trainer's Manual (MicroSave - Market-led solutions for financial services and MEDA, 2007). 